\title{
Gender, Informal Employment and Trade Liberalization in Mexico
}

\section{Sarra Ben Yahmed and Pamela Bombarda}

\begin{abstract}
This paper studies how import liberalization affects formal employment across gender. The theory offers a mechanism to explain how male and female formal employment shares can respond differently to trade liberalization through labor reallocation across tradable and nontradable sectors. Using Mexican data over the period 1993-2001, we find that Mexican tariff cuts increase the probability of working formally for both men and women within four-digit manufacturing industries. The formalization of jobs within tradable sectors is driven by large firms. Constructing a regional tariff measure, we find that regional exposure to import liberalization increases the probability of working formally in the manufacturing sector for both men and women, and especially for men. However in the service sectors, the probability of working formally decreases for low-skilled women.
\end{abstract}

JEL classification: F11, F16, F63, O17

Keywords: formal and informal labor, gender, trade liberalization, Mexico

\section{Introduction}

Trade integration episodes are expected to foster economic development by reallocating resources towards more productive sectors and firms. However, the impact of international trade on labor markets is controversial, as it can also contribute to an increase in inequality (see Goldberg and Pavcnik [2007]; and Hanson [2007], among others). Labor markets in developing countries are characterized by a dual system where formal and informal jobs coexist, and by gender inequalities. Informal jobs tend to offer lower earning opportunities, worse working conditions, and few social safety nets compared to formal jobs. Therefore, reducing informality rates, as well as gender gaps, is a crucial aspect of policies tackling

Sarra Ben Yahmed (corresponding author) is a researcher at the Centre for European Economic Research (ZEW), Mannheim, Germany; her email address is Sarra.BenYahmed@zew.de. Pamela Bombarda is an assistant professor at Université de CergyPontoise, THEMA (UMR CNRS 8184), France; her email address is pamela.bombarda@u-cergy.fr. The authors are grateful to the editor and two anonymous referees for very valuable comments and constructive suggestions. The authors would also like to thank Benjamin Aleman-Castilla, Mariano Bosch, and Marco Manacorda for helping us with the ENEU data; Eric Verhoogen for sharing the correspondence between Mexican CAE and CMAP classifications with us; and Beata Javorcik for providing us with the Mexican tariff data. For helpful comments, the authors also thank Clément Bosquet, Elisa Gamberoni, Stefania Marcassa, Gianluca Orefice, and Philipp Sauré, as well as participants at several seminars and conferences. All errors are our own. This research has been conducted as part of the project Labex MME-DII (ANR11-LBX-0023-01), the ANR-DFG (France-Germany) project "Local Labour Markets: The Causes and Consequences of Spatial Differences in Labour Market Outcomes Across Cities," and the SEEK-2016 project "Fiscal and Labour Policy Institutions and Inequality". A supplementary online appendix for this article can be found at The World Bank Economic Review website. 
the issues of inequality and poverty. Recent studies have shown that trade liberalization affects informality rates (Dix-Carneiro and Kovak [2018]; McCaig and Pavcnik [2015]; and references herein), as well as gender differences in the labor market (Juhn, Ujhelyi, and Villegas-Sanchez [2014]; Sauré and Zoabi [2014]; Gaddis and Pieters [2017], among others).

This paper is the first to present a theoretical and empirical analysis of the relationship between trade integration and gender-specific formal employment. Exploiting sharp cuts in Mexican import tariffs during the 1990s, this analysis offers a comprehensive picture of the effect of import liberalization on formality rates across gender, both at the sectoral and local labor market level. A joint analysis of informal employment and its gender composition is necessary to improve our understanding of the impact of globalization on the labor market, and it is motivated by several observations. Firstly, sectors have different female labor shares as well as different shares of formal jobs. As trade integration benefits some sectors at the expense of others, it is likely to change formal employment shares, and to do so differently for men and women. Secondly, trade liberalization is likely to generate a "formal-biased technological change" since it favors the most productive firms that are more intensive in formal labor because of their size and technology. Finally, there is evidence in support of a stronger complementarity between capital and female labor than between capital and male labor. ${ }^{1}$ These differences in the substitution between female and male labor to capital may also affect the relationship between trade liberalization and labor allocations.

The analysis is developed in three steps. The first step consists in presenting some facts on employment patterns in Mexico over the period 1993 and 2001. Considering both manufacturing and service industries, we observe that (i) employment and formal employment shares have declined in service sectors while they have increased in manufacturing sectors; (ii) formal labor shares are greater for women than for men both in manufacturing and in service sectors; and (iii) female intensity in formal jobs has increased only in manufacturing sectors. ${ }^{2}$ In a second step, a general equilibrium model shows how trade liberalization affects the formal employment shares of men and women in different ways. Following Blum (2008) and Dix-Carneiro and Kovak (2015), the multisector Ricardo-Viner model features two types of labor. This framework allows for formal and informal jobs and introduces sectoral heterogeneity in formal job intensity. The model predicts that trade liberalization increases the demand for formal labor if comparative advantage sectors are relatively more intensive in formal jobs. ${ }^{3}$ Under certain conditions, the effects differs across men and women. Trade liberalization increases the demand for male labor by a larger amount relative to female labor in formal jobs if comparative advantage sectors are relatively more intensive in formal jobs, and if male labor is relatively more substitutable for capital than female labor. ${ }^{4}$

In a third and final step, an empirical analysis provides estimates of the effect of Mexican import tariffs on the probability of holding a formal job for men and women. The focus is on import liberalization in Mexico, but the results are also robust to controlling for reductions in U.S. import tariffs applied on Mexican products (export liberalization). Mexico represents an interesting case study for at least three reasons. First, among North American Free Trade Agreement (NAFTA) members, Mexico was the country with the highest tariffs and experienced the largest cut during the NAFTA phase-in. Over the period 1993-2001, Mexican import tariffs on U.S. products declined on average by 14 percent. Second, Mexico

1 Black and Spitz-Oener (2010) show how technological change can increase women's productivity relative to men's through a decline in routine task inputs. Juhn, Ujhelyi, and Villegas-Sanchez (2014) develop a model where firms upgrade their technology with trade integration, which lowers their need for physically demanding tasks and thus increases their demand for female labor.

2 The analysis includes manufacturing sectors, also referred to as tradable sectors, and service sectors, also called nontradable sectors.

3 In supplementary online appendix S2, available at The World Bank Economic Review website, fig. S2.1 shows that over the 1990s Mexican manufacturing sectors with large net export shares are on average more intensive in formal labor than manufacturing sectors with low net export shares.

4 This has been a common assumption since the seminal article of Galor and Weil (1996). 
has a large informal sector, which increased in the 1990s (Jütting and De Laiglesia 2009). Finally, the Mexican labor market exhibits striking gender differences. The extremely low female labor force participation is one illustration of this: less than 40 percent of women participated in the labor force in the early 1990s, and this share remained below 50 percent in the early 2000s.

The empirical analysis is based on individual data from the Mexican labor force Encuesta Nacional de Empleo Urbano (ENEU). We focus on wage employment and define informal employees as those who do not have access to health insurance and social security coverage, which are mandated benefits for legal labor contracts. We estimate two specifications using a linear probability model. First, we exploit timevariation in four-digit industry tariffs and find that individuals working in an industry experiencing the average reduction in Mexican tariffs of 14 percentage points experience an increase in the probability of holding a formal job by 2 percentage points relative to individuals in industries facing no reduction in tariffs. This formalization of jobs within industries is driven by big firms, while informality increases with import liberalization in very small firms. These findings are consistent with a reallocation of employment into trade-oriented firms that are larger and more intensive in formal jobs.

Second, we adopt a local labor market approach and disentangle the effects of import liberalization across tradable and nontradable sectors. To do so, we construct a measure of exposure to import tariffs at the municipality level, where the sectoral tariffs are weighted by sectoral employment shares in each municipality. ${ }^{5}$ Exploiting the regional variation in exposure to import tariffs, we find that men living in a municipality experiencing the average reduction in tariffs of 14 percentage points are almost 6 percentage points more likely to hold a formal job than men in municipalities facing no reduction in tariffs. However, women are not affected on average. We then disentangle the overall effect into a direct effect on manufacturing sectors and an indirect effect on service sectors. In the manufacturing sector, import liberalization increases the probability of working in the formal sector for both women and men. The formalization effect in the overall manufacturing sector is larger than the effect within four-digit manufacturing sectors. This suggests that regional import liberalization generates labor reallocation across four-digit manufacturing industries, which contributes to a formalization of employment in the manufacturing sector. Moreover, the formalization effect is bigger among men, in particular for highly educated workers. These results are consistent with a Ricardo-Viner model in which the comparative advantage (CA) sectors are more intensive in formal labor and where male labor is relatively more substitutable for capital than female labor.

In the service sectors, in contrast to the manufacturing sectors, trade liberalization increases the probability of working informally only among low-skilled women. Using a different sample of working-age individuals, which includes individuals not in paid employment, we find that the increase in informality in the service sector is partly related to women entering the labor market with informal jobs in the service sector. These results are robust to controls for U.S. tariffs on Mexican goods.

The paper is structured as follows. Section 2 describes the novel contributions of this paper with respect to the existing literature. Section 3 provides a description of the data and an industry decomposition of changes in the formal employment share. Section 4 proposes a theoretical framework and presents predictions to be tested. Section 5 describes the empirical strategy and results for the industry-level approach. Section 6 provides the results of the local labor market approach. Finally, we conclude in section 7.

\section{Related Literature}

This paper is related to several strands of literature. Firstly, it relates to studies on trade and informality. A branch of this literature has paid attention to industry-level response of formal and informal employment to trade shocks. Goldberg and Pavcnik (2003); Menezes-Filho and Muendler (2011), and

5 The term "region" refers to local labor markets. Notice that these local labor markets correspond to "municipalities" in the empirical part with ENEU data. 
Bosch, Goñi-Pacchioni, and Maloney (2012) find no or minimal effect of trade liberalization on informality within sectors in Brazil. Paz (2014) and McCaig and Pavcnik (2015) find that reductions in trading partner tariffs decrease informality in Brazil and Vietnam respectively. ${ }^{6}$ In contrast, we look at how changes in Mexican import tariffs on U.S. products affected formal employment in Mexico during the 1990s. Similarly to Aleman-Castilla (2006), we find that a reduction in the Mexican tariff increases formality rates within-industry. This result is robust to controlling for U.S. import tariffs. The analysis contributes to the literature on trade and informality at the sector level with several novel insights. First, within four-digit industries women and men are similarly affected in their formal employment probability. Second, the effect differs across firms' size. Considering trade liberalization in Argentina, Cruces, Porto, and Viollaz (2017) find that industries with a large share of employment concentrated in small firms experience an increase in informality. We complement their analysis using individual data and find that workers in small firms have a higher probability of holding an informal job when sectoral tariffs decline. On the contrary, workers in bigger firms experience an increase in formal employment probability with a drop in the sectoral tariff.

This work also relates to the literature that adopts a local labor market approach to analyze the relationship between regional trade exposure and labor market outcomes such as wages (Chiquiar [2008] for Mexico; Kovak [2013] and Dix-Carneiro and Kovak [2015] for Brazil), employment (Autor, Dorn, and Hanson [2013] for the United States; Dix-Carneiro and Kovak [2017] for Brazil and references herein), child labor and poverty (Edmonds, Topalova, and Pavcnik 2009, 2010; Topalova 2010; Kis-Katos and Sparrow 2015). More recently, Autor, Dorn, and Hanson (2018) studied how adverse local labor market shocks due to rising import penetration affect marriage, fertility, and children's living circumstances. Our theoretical model is related to Dix-Carneiro and Kovak (2015), where they use two types of workers. Unlike them, we explore gender differences, rather than educational differences, and we focus on employment rather than wages. Moreover, the formality dimension is new in the theory. There are not only two types of workers, but also two types of jobs, formal and informal. The empirical analysis presented in this paper complements the literature on trade and local labor markets by considering gender differences across formal and informal employment during Mexican trade liberalization in the 1990s. Previous work on developing countries found limited effects of import liberalization on informality (Goldberg and Pavcnik [2003]; Menezes-Filho and Muendler [2011]; Bosch, Goñi-Pacchioni, and Maloney [2012] among others). Adopting a long difference identification strategy for Brazil, Dix-Carneiro and Kovak (2017) find that regions facing larger tariff cuts experienced prolonged declines in formal sector employment and earnings relative to other regions. Section 6 points out reasons why results on Mexico differ from results on other countries. The discussion considers the specific sample used (only urban areas), methodology (shorter-run evaluation) and country setting.

Finally, the approach adopted in this paper closely relates to a growing number of papers emphasizing the gender-specific effects of international trade. This literature proposes different channels to investigate the effect of trade liberalization on gender gaps in labor force participation and wages. Trade liberalization can contribute to a reduction in the gender gap due to taste-based discrimination through a competition effect (see Black and Brainerd [2004] and Ben Yahmed [2012] among others). Other papers stress the importance of male and female differences in productive characteristics and how their returns evolve with trade integration (Aguayo-Tellez, Airola, and Juhn 2010; Juhn, Ujhelyi, and Villegas-Sanchez 2013; Juhn, Ujhelyi, and Villegas-Sanchez 2014; Sauré and Zoabi 2014; Do, Levchenko, and Raddatz 2016). Unlike previous studies on Mexico, such as Aguayo-Tellez, Airola, and Juhn (2010) and Juhn, Ujhelyi, and Villegas-Sanchez (2014), this paper focuses on the impact of Mexico's trade liberalization on gender differences considering not only formal employment but also informal employment. The results show that trade liberalization has a gender-specific effect on formality, especially 
in service sectors. To account for shifts between employment and non-employment, the analysis is extended to the whole sample of the working-age population. Differently from Gaddis and Pieters (2017) who use Brazilian data, we find that the Mexican trade liberalization over the 1990s contributed to a small increase in female paid employment probability, but did not lead to a significant change in male paid employment probability. While Gaddis and Pieters (2017) do not differentiate formal from informal employment, we show that this dimension is important. The smaller formalization effect of trade among women is partly due to women moving from non-employment into informal jobs with exposure to tariff reductions. To the best of our knowledge, this is the first paper to investigate the effects of trade liberalization on formal and informal employment by gender.

\section{Formal Employment Shares in Mexico}

This section presents the data and empirical facts about female and male formal employment shares in Mexico over the 1900s.

\section{Data}

The data used in this study come from the Encuesta Nacional de Empleo Urban (ENEU), which is a quarterly labor force survey conducted by the Mexican National Institute of Statistics (INEGI). This survey provides information on individuals' socio-economic characteristics, firm size, industry affiliation at the four-digit level clasification actividades economicas (CAE), and location at the municipality level. ${ }^{7}$ The survey is representative of cities with over 100,000 inhabitants, and covers only urban areas. The primary sampling units are municipalities. Over time the sample size of the survey has constantly increased as cities were added every year. The total number of municipalities over the the period 1993-2001 is 216, with municipalities entering and exiting every year. All municipalities reported in each year over the period 1993-2001 are included in the sample. ${ }^{8}$

The main sample is restricted to working individuals between the ages of 16 and 60 . We distinguish three types of employment: formal and informal wage employment, and self-employment. ${ }^{9}$ Informal wage workers are employees who report not having health insurance or social security coverage, although their status should entitle them to these mandated benefits. Self-employed individuals report being "ownaccount workers" (trabajador por su cuenta) as their main job. Self-employed individuals differ from employers as they own very small businesses; more than 80 percent of them have no employees. However the ENEU survey does not make it possible to clearly distinguish between formal and informal self-employment. Therefore, our preferred measure for distinguishing formal from informal employment only considers wage workers. A robustness check presents results with another definition of informal employment that includes both informal wage employment and self-employment. Additional descriptive statistics on formal and informal employees and the self-employed are provided in table S1.2.

To capture variation in trade liberalization, the ENEU labor force survey is merged with Mexican import ad valorem tariffs on U.S. products at the four-digit level from Iacovone and Javorcik (2010). Additionally, since NAFTA also lowered U.S. tariffs on Mexican exports to the United States, it is important to control for this contemporaneous change in trade policy. Therefore, a sensitivity analysis presents

7 This survey has been used by several authors, including for example Robertson (2004); Verhoogen (2008), and Bosch and Manacorda (2010).

8 See table S1.1 in the supplementary online appendix for details on the sample size. Alternative approaches suggest focusing on the subset of municipalities that are always surveyed in the sample period. The results are not affected by the sample choice, which indicates that the composition of municipalities in the ENEU is not correlated with changes in trade policy.

9 To account for shifts between employment and non-employment, the analysis is replicated using the sample of workingage individuals, including individuals in unemployment and out of the labor force. 
results with U.S. import tariffs from Feenstra, Romalis, and Schott (2002) as control variables. ${ }^{10}$ More details on our industry and regional tariff measures are provided in section 4 and in the supplementary online appendix S1.

\section{Trade Liberalization and Employment Shares}

After a long period of import substitution strategy, Mexico started to move toward a liberalized trade regime in the 1980s. In 1994 it joined NAFTA and substantially lowered its import tariffs on the U.S. and Canadian markets. Qualitative analysis of the political economy of liberalization in Mexico indicates the reduction in bilateral tariff barriers as the major economic goal of the government. To recover from difficult economic times throughout most of the 1980s, the government tried to stimulate economic growth through entering NAFTA. The reduction of almost all tariffs on U.S. products resulted in an average reduction of 14 percentage points, from more than 15 percent in 1993 to less than 1.5 percent in 2003. Figure S1.1 in supplementary online appendix S1 shows that industries with the highest pre-NAFTA tariff levels (in 1993) experience the biggest tariff declines between 1993 and 2001, with a correlation of $-0.91 .{ }^{11}$ This pattern is similar to the one reported for Colombia by Goldberg and Pavcnik (2005) and for Brazil by Kovak (2013). Since the reduction in tariffs was almost entirely determined by preliberalization levels and given that we control for sector time-invariant characteristics, we are not concerned that Mexican tariff cuts are correlated with concentration of formal firms across tradable industries. ${ }^{12}$

Figure 1 shows the evolution of employment shares and formal employment shares in the manufacturing and service sectors, and the drop in the average Mexican import tariff on U.S. products during the 1990s.

Mexican import tariffs on U.S. products were reduced on average by 14 percentage points, from more than 15 percent in 1993 to less than 1.5 percent in 2003 (panel a). At the same time, the employment share in the manufacturing sector has increased at the expense of the employment share in the service sector (panels $a$ and $b$ ). The drop in the Mexican average tariff applied to U.S. products also coincides with the reallocation of formal employment from service to manufacturing sectors (panel $c$ ).

Figure 2 shows how formal employment has changed differently for male and female employees during the trade liberalization period. Overall, female employees have a higher formality rate (between 80 and 75 percent) than male employees (between 70 and 74 percent). However, the gender gap in the formality rate among wage workers has been shrinking. It was almost 10 percentage points in 1993, and was reduced to about 4 percentage points in 2001. The formality rate has increased in the manufacturing sectors for both men and women (panel $b$ ). In contrast, in the service sector, the formality rate has decreased for women, while it has remained fairly stable for men (panel $c$ ). The next section provides a decomposition analysis of changes in the female share among formal employees.

\section{Decomposition of Changes in Formal Employment Shares}

Changes in men and women's formal employment shares (henceforth FS) can be decomposed into withinand between-industry changes. The decomposition is expressed as follows:

$$
\Delta F S_{g t}=\sum_{s} \Delta F S_{g s t} \times E_{g s}+\sum_{s} \Delta E_{g s t} \times F S_{g s}
$$

where $F S_{g t}$ denotes the share of formal employees in total employment of group $g=\{f, m\}$, where $f$ denotes female and $m$ denotes male. $\Delta F S_{g t}=F S_{g t}-F S_{g t-1}$ is the change in the formal employment share over the period. $F S_{g s t}$ denotes the share of formal employees in industry $s$ employment of group $g$ and $E_{g s}$ is industry $s$ employment of group $g$.

10 See Schott's web page: http://faculty.som.yale.edu/peterschott/sub_cv.htm.

11 The only exception concerns the manufacture of liquors, for which tariff has remained high.

12 See the supplementary online appendix S1 for more detailed discussion on tariff exogeneity. 
Figure 1. Employment Trends and Mexican Tariffs

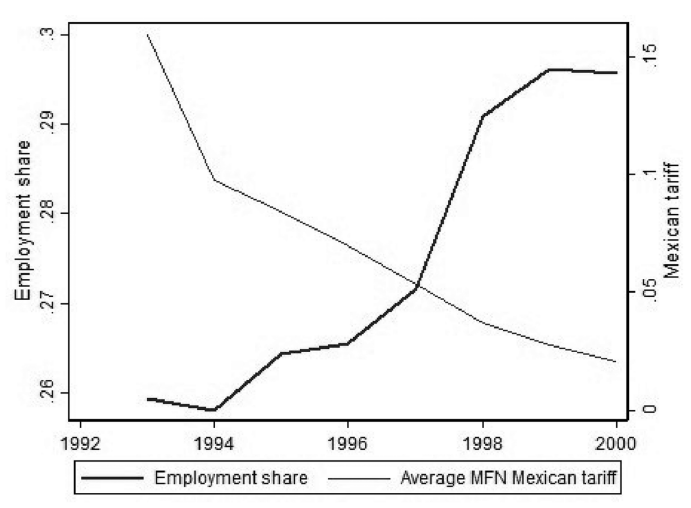

(a) Employment share in manufacturing sectors

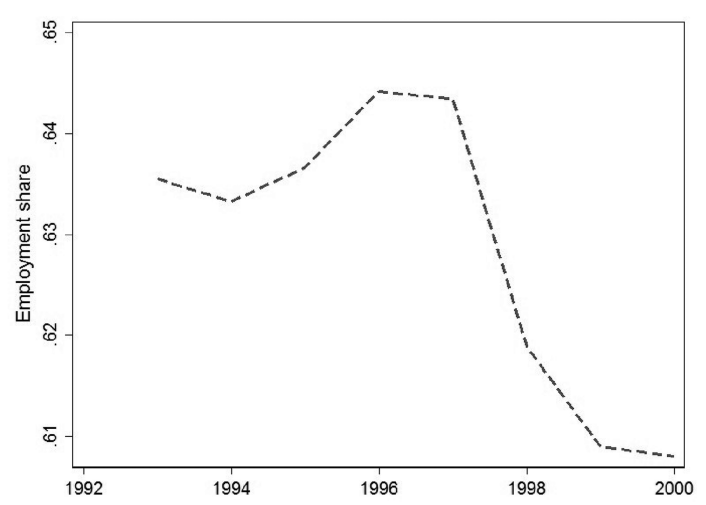

(b) Employment share in service sectors

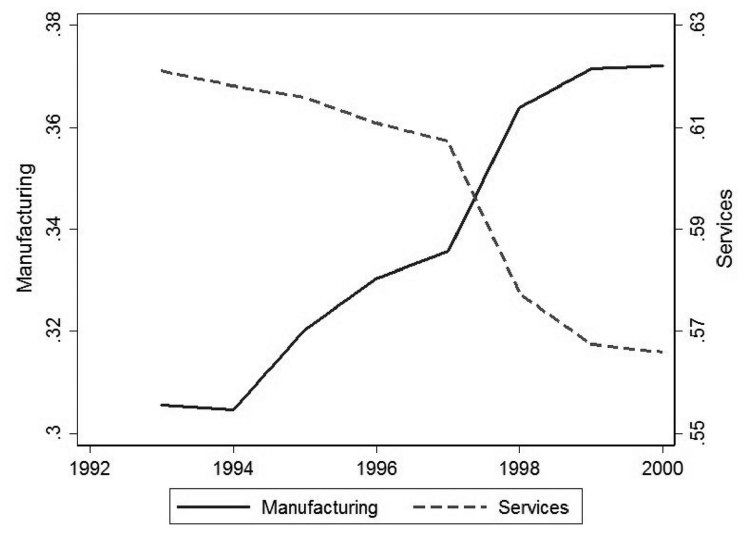

(c) Formal employment shares in manufacturing and services

Source: Authors' calculations based on the National Urban Employment Survey from the National Institute of Statistics and Geography, Mexico. Note: MFN, most-favored nation tariffs.

The first term on the right-hand side of equation (1) is the within-industry component and represents the part of the aggregate change in $F S_{g t}$ due to changes in industry-specific $F S_{g s t}$, holding constant the employment shares of industries. The second term is the between-industry component. It reflects changes in the aggregate $F S_{g t}$ due to changes in the employment shares of industries, holding constant the industryspecific $F S_{g s t}$.

Tables 1 and 2 present the decomposition using a different level of industry disaggregation and a different sample of industries. The decomposition is done first over the entire sample period, and then using two different sub-samples: 1994-1998 and 1998-2001. Table 1 presents the decomposition into between- and within-industry changes at the one-digit level of disaggregation using the sample of workers in the manufacturing and the service sectors. 
Figure 2. Formality Rate among Wage Workers

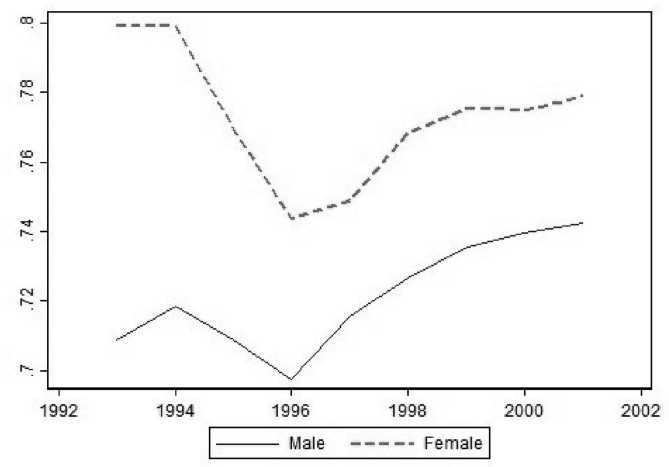

(a) All sectors

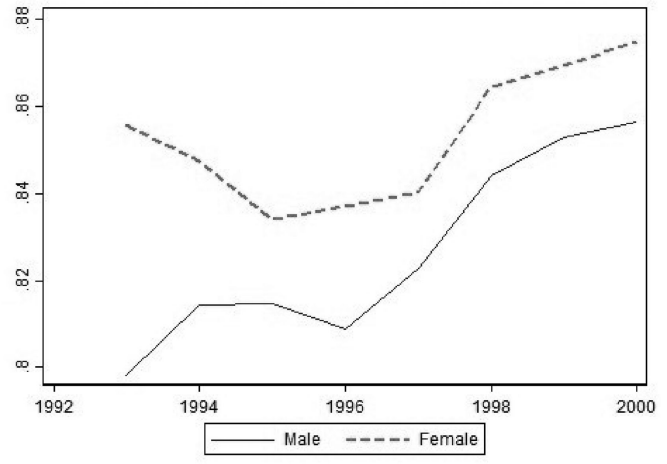

(b) Manufacturing

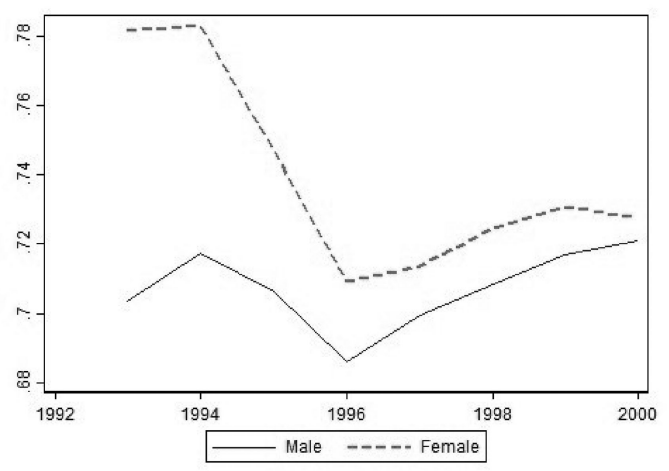

(c) Services

Source: Authors' calculations based on the National Urban Employment Survey from the National Institute of Statistics and Geography, Mexico.

Table 1. Decomposition across One-Digit Sectors

\begin{tabular}{lccc}
\hline & $\begin{array}{c}\text { Total } \\
(1)\end{array}$ & Within & Between \\
& & $(2)$ & \\
& & $1994-2001$ & .007 \\
Female & -.02 & -.027 & .003 \\
Male & .024 & .021 & .007 \\
& & $1994-1998$ & .004 \\
Female & -.031 & -.038 & \\
Male & .008 & .004 & -.001 \\
& & $1998-2001$ & 0 \\
Female & .011 & .011 & .016 \\
Male & .016 & &
\end{tabular}

Source: Authors' calculations based on the National Urban Employment Survey from the National Institute of Statistics and Geography, Mexico.

Note: Two one-digit sectors, manufacturing and service sectors, only. Numbers multiplied by 100 represents changes in percentage points. For example, the share of formal employment among female employees decreased by 2 percentage points between 1994 and 2001. 
Table 2. Decomposition across Four-Digit Manufacturing Sectors

\begin{tabular}{lccc}
\hline & $\begin{array}{c}\text { Total } \\
(1)\end{array}$ & Within & Between \\
& & $(2)$ & $(3)$ \\
\hline Female & .021 & $1994-2001$ & -.007 \\
Male & .039 & .028 & .012 \\
& & .027 & -.011 \\
Female & .006 & $.094-1998$ & .011 \\
Male & .028 & .017 & .002 \\
& .012 & .011 & .004 \\
Female & .011 & .007 & \\
Male & & & \\
\hline $\begin{array}{l}\text { Source: Authors' calculations based on the National Urban Employment Survey from the National Institute of Statis- } \\
\text { tics and Geography, Mexico. }\end{array}$ &
\end{tabular}

Column (1) in table 1 shows that the share of formal employees among male employees has increased in the overall economy by 2.4 percentage points, but it has decreased among women by 2 percentage points. These changes are driven by within one-digit industry changes. In the manufacturing sector, the FS has substantially increased over the period, especially for men, while the $F S$ in the service sector was in decline until 1996 and especially for women (see fig. 2). Reallocation of employment from the service to the manufacturing sectors (between-industry change) contributed to a small increase in the overall FS.

Table 2 focuses only on the manufacturing sectors and relates changes in aggregate FS into betweenand within-four-digit industries changes. Between 1994 and 2001, women's FS increased by more than 2 percentage points, and by almost 4 percentage points for men. This increase in the overall manufacturing FS is explained by both within- and between-four-digit industry changes. Within-industry changes contribute positively to the increase in the FS for both men and women. The reallocation of labor into manufacturing industries with a high $F S$ has also contributed to the increase in the aggregate $F S$, except between 1994 and 1998 for women.

Overall, the increase in the FS has been more pronounced for men than for women. Both within- and between-industry changes explain changes in the share of formal jobs in wage employment, but withinindustry changes explain a bigger share of the aggregate change. In the following sections we investigate theoretically and empirically how trade liberalization contributes to those changes. The theoretical model focuses on how trade liberalization affects formal employment shares through between-industry reallocation in different ways for men and for women. We borrow from recent trade models to explain the changes in formal employment shares within tradable industries. We then conduct an empirical investigation of the impact of trade on female and male formal employment through both within- and between-industry reallocation.

\section{Theoretical Framework}

The Ricardo-Viner model developed in this section follows Kovak (2013) in using Jones (1975) to model each region within a country as a specific-factor economy. Then, similarly to Blum (2008) and Dix-Carneiro and Kovak (2015), we consider a structure with two labor factors, in this case female and male labor, and analyze labor reallocation across tradable and nontradable sectors. Finally, to study how employment reallocation across sectors following trade liberalization affects female and male formal 
employment, we introduce sectoral heterogeneity in formal job intensity. The following sections present the setup of the model and then highlight the effect of trade liberalization on male and female formality rates at the regional level.

\section{The Setup}

The country is composed of several regions, indexed by $r$, that produce $\mathrm{N}$ goods, $\mathrm{M}$ of which are internationally tradable and can be either imported or exported. Since the focus is on a particular region, we suppress the subscript $r$ on all terms. Production uses capital, $K$, and two types of labor, female and male labor, $L_{f}$ and $L_{m}$. Labor is assumed to be supplied inelastically, fully employed, and perfectly mobile across industries but not across regions. Capital is not mobile between sectors or regions in the short run. Technologies may differ across sectors, but are the same across regions within each sector. Production exhibits constant returns to scale, and factors and goods markets are competitive. All regions face the same prices for the tradable goods, which are taken as given on the international market.

Each sector $s$, either tradable or nontradable, is characterized by an exogenous share of formal jobs, $\alpha_{s}$. More specifically, men and women can be hired as formal or informal workers within the same sector. Formal employment for each gender group $g$, with $g=\{f, m\}$, and sector $s$, is defined as $L_{\varphi g s}=\alpha_{s} L_{g s}$, where $\varphi$ stands for formal. The term $\alpha_{s}$ captures sector heterogeneity in formal labor intensity. ${ }^{13}$

This set-up generates a link between male and female formality rates and trade liberalization, which is the focus of the next section. The model is presented in its entirety in the online appendix S2.

\section{Trade and Formal Employment at the Sector Level}

The model does not endogenize within-industry changes in formal employment. Changes in the share of formal labor in a sector, $\hat{\alpha}_{s}=\hat{L}_{\varphi g s}-\hat{L}_{g s}$ could increase with trade through two channels. First, firms may increase their demand for formal labor with "formal-biased technological change." Exporters may invest in new technologies that require firm-specific knowledge or specific training of workers, giving firms incentive to retain workers and provide formal contracts. Second, trade liberalization can increase the share of formal labor at the sectoral level by reallocating employment to trade-oriented firms, which are more intensive in formal jobs (see Aleman-Castilla [2006]; Nataraj [2011]; and McCaig and Pavcnik [2015] among others). In fact, it is well established that trade integration induces employment reallocation across heterogeneous firms within sectors. Since trade-oriented firms tend to be larger and employ more skilled workers, they should also be more likely to hire formal workers.

The theoretical model of this paper does not focus on changes in $\alpha_{s}$. Rather, we use the model to explore the effects of trade liberalization on the regional gender gap in formality rates through labor reallocation between sectors. We discuss in section 4 how trade liberalization may affect the formality rate of men and women at the regional level in different ways.

\section{Trade and Formal Employment at the Regional Level}

This section adopts a local labor market approach and investigates how the demand for formal labor evolves with trade liberalization in a regional economy. Considering a particular region and thus suppressing the subscript $r$ on all terms, the share of group $g$ formal employment is given by:

$$
\frac{L_{\varphi g}}{L_{g}}=\frac{\sum_{s} \alpha_{s} L_{g s}}{\sum_{s} L_{g s}} .
$$

Notice that the change in formal employment share can be written as: $\hat{L}_{\varphi g}-\hat{L}_{g}$. Since the labor supply is fixed at the regional level, $\hat{L}_{g}=0$, the change in the formal labor share is equal to the change in the level

13 We assume that formal labor intensity in a sector is the same across gender. The results would hold if we would allow the formal labor intensity to differ between men and women within each sector. 
of formal labor:

$$
\begin{gathered}
\hat{L}_{\varphi f}=\sum_{s} \lambda_{\varphi f s} \times \hat{L}_{f s}\left(p_{s}, \sigma_{f k, s}^{f}, \sigma_{f k, s}^{m}, \theta\right), \\
\hat{L}_{\varphi m}=\sum_{s} \lambda_{\varphi m s} \times \hat{L}_{m s}\left(p_{s}, \sigma_{m k, s}^{m}, \sigma_{m k, s}^{f}, \theta\right),
\end{gathered}
$$

where $\lambda_{\varphi f s}=\frac{\alpha_{s} L_{f s}}{L_{\varphi f}}$ and $\lambda_{\varphi m s}=\frac{\alpha_{s} L_{m s}}{L_{\varphi m}}$ represent the fraction of female and male formal employment in industry $s$ respectively. $\hat{L}_{f s}$ and $\hat{L}_{m s}$ represent the change in the demand for female and male labor in sector $s$, which depend on different elements. Firstly, on the price of the good produced in sector $s, p_{s}$. Secondly, on the elasticity of substitution between factor $g$ and the specific capital $K_{s}$ with respect to the relative price of factors $L_{g}$, and $K_{s}$; elasticities are denoted $\sigma_{f k, s}^{g}$ and $\sigma_{m k, s}^{g}$. And finally on a vector $\theta$ representing the cost shares of each factor of production, $\theta=\left\{\theta_{f s}, \theta_{m s}, \theta_{k s}\right\} .{ }^{14}$

Moving from autarky to trade integration corresponds to an increase in the price of the goods in which the country has CA, $\hat{p}_{s}>0$. As explained in supplementary online appendix S2, the change in sector $s$ labor demand goes in the same direction as the price change. Therefore, trade liberalization affects female and male labor demand in a given sector in the same direction. However, the proportion of this change will differ, and this is because the substitution between male labor and capital differs from the substitution between female labor and capital.

To understand what happens to employment at the regional level, we need to consider the endowment of the industry-specific factor, $K_{s}$, across regions. In the model, if region $r$ is relatively well endowed with industry $s$ specific factor, then that region allocates a greater share of its labor to industry $s$. Similarly, an increase in the price of that industry $s$ has a larger positive effect on employment in that region $r$ compared to other regions. Therefore, the formalization of regional employment is greater in comparative advantage sectors that are larger, more intensive in formal labor (i.e. large $\lambda_{\varphi g s}$ ), and with a more elastic labor demand, meaning that they absorb a larger amount of labor from non-CA sectors. ${ }^{15}$

Prediction 1. At the regional level, formal employment increases if CA sectors in that region are larger, more intensive in formal labor, and have more elastic labor demands than the comparative disadvantage sectors.

The model also gives a prediction about changes in female and male formal employment shares at the regional level. Using equations (3) and (4), the gender difference in the change in formal employment is:

$$
\hat{L}_{\varphi m}-\hat{L}_{\varphi f}=\sum_{s} \lambda_{\varphi m s} \times \hat{L}_{m s}\left(p_{s}, \sigma_{f k, s}^{f}, \sigma_{f k, s}^{m}, \theta\right)-\sum_{s} \lambda_{\varphi f s} \times \hat{L}_{f s}\left(p_{s}, \sigma_{m k, s}^{m}, \sigma_{m k, s}^{f}, \theta\right)
$$

where $\hat{L}_{m s}$ and $\hat{L}_{f s}$ are characterized by equations (13) and (14) in supplementary online appendix S2. Equation (5) enables us to analyze how a particular region's gender gap in formal employment is affected by changes in the price of goods.

First, we follow Galor and Weil (1996) and assume that male labor is relatively more substitutable for capital than female labor. In this case, after a price increase, male labor demand should increase more than female labor demand in CA sectors. Second, if CA sectors are more intensive in formal labor than non-CA sectors, then trade liberalization also increases the overall share of formal jobs. This happens

14 See equations (11) and (12) in supplementary online appendix S2 for more details.

15 Note that equations (3) and (4) can be expressed for all sectors $s$, and for a subset of sectors such as the tradable sectors only. 
because labor is reallocated from less to more formal intensive sectors. ${ }^{16}$ Under these two conditions, trade liberalization generates more male than female formal jobs.

Prediction 2. Within a region, trade liberalization increases the share of male formal employment by a larger amount relative to female labor demand if: (a) in CA sectors, male labor is relatively more substitutable for capital than female labor, and (b) CA sectors are larger and more intensive in formal labor than non-CA sectors.

Although all regions face the same changes in international prices, each region has a different industry mix, meaning that the effect of trade on the gender gap in formal employment differs across regions. The magnitude of the change in regional gender gap in formal employment depends on the size of the CA sectors and on the concentration of men and women across sectors in that region. More specifically, in a given region, if men are concentrated in relatively large CA sectors, then this region experiences a greater increase in the formal employment of men relative to women.

\section{From Theory to Empirics}

This section describes the link between the theoretical model and the empirical specification that is used to study the effects of trade liberalization on formal employment across gender in Mexico.

Equation (5) shows that the ge thender gap in formal employment shares is affected by a weighted sum of sectoral prices. Changes in sectoral tariffs affect sectoral prices. We construct a weighted sum of Mexican import tariff at the municipality level to capture the effect of import liberalization. This regional measure of tariff enables us to explore potential labor reallocation across sectors $s$, tradable and nontradable, and to highlight spillover effects of trade liberalization on nontradable sectors. Following the literature on the regional effects of trade, we use an employment-weighted average tariff of tradable industries active in each municipality. Tariffs are defined at the industry level and are the same across regions. Since we apply weights defined at the industry and municipality level, the regional tariffs vary across municipalities and over time.

Following the theoretical model, we construct weights using formal employment in each industry and municipality. Additionally, the theoretical mechanism indicates that men and women in a given region might be exposed to trade liberalization in different ways because they work in different industries facing different tariff declines. Therefore, the measure also uses gender-specific employment weights. The local tariff varies across municipalities, years and gender. This weighted-average tariff is related to other measures used in the literature on local effects of trade with heterogeneous labor as in Autor, Dorn, and Hanson (2018) for men and women, and in Dix-Carneiro and Kovak (2015) for skilled and unskilled workers.

We follow Kovak (2013) and do not include nontradable sectors in the weighted average. Therefore, the weights only consider formal employees in tradable industries in each municipality. ${ }^{17}$ To avoid endogeneity issues due to changes in the industry mix over time, the weights are based on the employment structure of each municipality in the first year in which the municipality enters the survey. ${ }^{18}$

16 Combining export data from Centre d'Études Prospectives et d'Informations Internationales (CEPII) with the ENEU survey, fig. S2.1 in supplementary online appendix S2 shows that over the 1990s Mexican manufacturing sectors with large net export shares are on average more intensive in formal labor than manufacturing sectors with low net export shares.

17 An alternative approach consists in assigning a zero tariff to nontradable industries, as in Topalova (2010). This approach is preferable only if workers cannot freely move from tradable to nontradable sectors. Using this alternative local tariff measure, which accounts for the share of people working in the nontradable sectors, confirms our main findings. Results are available upon request.

18 We have also computed the municipality average tariff using alternative weights, such as the employment structures in 1992, using the subset of municipalities already surveyed in 1992. The results do not change. 
Our gender-specific municipality tariff is then constructed as follows:

$$
\tau_{g r t}=\frac{\sum_{s}^{M} \text { Form Empl } l_{g r s, 1993} \times \tau_{s t}}{\sum_{s}^{M} \text { Form Empl } l_{g r s, 1993}}
$$

where $g$ indicates gender $g=\{$ female, male\}, $r$ indicates the municipality, $s$ the industry within the subset of manufacturing tradable industries, $s=1, \ldots, M$, and $t$ indicates time.

\section{Industry-Level Analysis}

The empirical analysis starts with an evaluation of the effects of trade policy on female and male sorting across formal and informal jobs within four-digit manufacturing industries. Even though the theoretical model is silent about within-industry reallocation, it is important to compare the regional response to reductions in import tariffs (estimated in section 6) with the within-industry response. Additionally, the within-industry approach can be compared to other results in the literature that focus on within-industry changes in tariffs. This section uses ad valorem Mexican import tariffs on U.S. products, $\tau_{s t}$, which vary across four-digit manufacturing sectors and years. ${ }^{19}$

We estimate a linear probability model (henceforth LPM) on the sample of formal and informal workers in manufacturing industries:

$$
F_{i s r t}=\alpha X_{i s r t}+\beta_{1} \tau_{s t}+\beta_{2} \tau_{s t} \times \text { female }+\mu_{s}+u_{r}+v_{t}+\epsilon_{i s t}
$$

where $F_{\text {ist }}$ is an indicator that takes the value 1 if individual $i$ is employed as a formal worker in industry $s$, region $r$ at time $t$, and 0 if the individual works as an informal employee. $X_{i s r t}$ is a vector of specific individual and household characteristics which includes a female dummy, age, age square, number of years of education, migration background, whether the individual lives with a partner, is the head of the household, the number of household members, the highest level of education in the household, and the share of household members holding a formal job. $\tau_{s t}$ is the Mexican import tariff at the four-digit industry level, and $\tau_{s t} \times$ female is the interaction term between the import tariff and the female indicator. $\mu_{s}, u_{r}$, and $v_{t}$ are a set of four-digit sector, municipality, and year fixed-effects. $\epsilon_{i s t}$ is the error term. To allow for different effects of trade liberalization on high-skilledmale formal employment versus lowskilled workers, the tariff variable is interacted with an indicator variable that equals 1 if the individual has more than nine years of education.

The coefficient $\beta_{2}$ captures the differential effect of trade liberalization on the probability of women holding a formal job compared to men. The sum between the coefficients $\beta_{1}$ and $\beta_{2}$ gives the average marginal effect of a change in the Mexican import tariff on the female probability of being a formal employee within a tradable sector. To account for firm heterogeneity, we use a similar specification as equation (7), and interact import tariffs with firm size. There are four firm-size categories: 1) firms with 10 or fewer employees, 2) firms with 11 to 50 employees, 3) firms with 51 to 250 employees, and finally 4) firms with more than 250 employees. To limit the risk of potential threats to identification, we later perform a set of robustness checks. First, we consider other channels that might be responsible for changes in the formal and informal employment. Then, we tackle additional concerns regarding threata to internal validity using an instrumental variable approach.

\section{Empirical Results within Tradable Industries}

The estimates of equation (7) are reported in table 3.

The negative coefficient associated with sectoral tariffs $\tau_{s t}$ indicates that trade liberalization leads to a formalization of jobs within four-digit manufacturing industries. According to column (1), individuals 
Table 3. Within-Industry Tariff Changes

\begin{tabular}{|c|c|c|c|c|c|}
\hline \multirow[t]{2}{*}{ Dependent variable } & \multicolumn{5}{|c|}{ Probability of Working Formally among Employees in Manufacturing Sectors } \\
\hline & $(1)$ & $(2)$ & (3) & (4) & (5) \\
\hline$\tau_{s t}$ & $\begin{array}{l}-0.140 * * * \\
(0.052)\end{array}$ & $\begin{array}{l}-0.142 * * * \\
(0.051)\end{array}$ & $\begin{array}{l}-0.135^{* * *} \\
(0.051)\end{array}$ & $\begin{array}{c}-0.130 * \\
(0.052)\end{array}$ & $\begin{array}{l}0.330 * * * \\
(0.083)\end{array}$ \\
\hline$\tau_{s t} \times$ female & & $\begin{array}{c}0.004 \\
(0.035)\end{array}$ & $\begin{array}{c}0.003 \\
(0.035)\end{array}$ & $\begin{array}{c}-0.011 \\
(0.037)\end{array}$ & \\
\hline$\tau_{s t} \times$ he & & & $\begin{array}{r}-0.016 \\
(0.017)\end{array}$ & $\begin{array}{r}-0.031 \\
(0.020)\end{array}$ & \\
\hline$\tau_{s t} \times$ he $\times$ female & & & & $\begin{array}{c}0.044 \\
(0.031)\end{array}$ & \\
\hline$\tau_{s t} \times$ firm $11-50$ & & & & & $\begin{array}{l}-0.313 * * * \\
(0.079)\end{array}$ \\
\hline$\tau_{s t} \times$ firm $51-250$ & & & & & $\begin{array}{l}-0.384 * * * \\
(0.084)\end{array}$ \\
\hline$\tau_{s t} \times$ firm 251+ & & & & & $\begin{array}{l}-0.448 * * * \\
(0.075)\end{array}$ \\
\hline Firm $11-50$ & & & & & $\begin{array}{l}0.432 * * * \\
(0.008))\end{array}$ \\
\hline Firm 51-250 & & & & & $\begin{array}{l}0.597 * * * \\
(0.010)\end{array}$ \\
\hline Firm 251+ & & & & & $\begin{array}{l}0.618 * * * \\
(0.009)\end{array}$ \\
\hline Observations & 674,206 & 674,206 & 674,206 & 674,206 & 672,173 \\
\hline R-squared & 0.262 & 0.262 & 0.262 & 0.262 & 0.426 \\
\hline Year FE & Yes & Yes & Yes & Yes & Yes \\
\hline Municipality & Yes & Yes & Yes & Yes & Yes \\
\hline 4-digit sector FE & Yes & Yes & Yes & Yes & Yes \\
\hline
\end{tabular}

Source: Authors' calculations based on the National Urban Employment Survey from the National Institute of Statistics and Geography, Mexico.

Note: The regressions are linear probability model (LPM) estimations of equation (7) for the period 1993-2001. Only manufacturing sectors. The dependent variable equals 1 if the individual is in formal wage employment and 0 if in informal wage employment. he is a dummy variable equal to 1 when the individual has more than 9 years of education. Individual controls include age and age ${ }^{2}$, years of education, a female dummy, whether she/he lives with a partner, is the head of the household, has migrated, the number of household members, the highest level of education in the household and the share of household members holding a formal job. Heteroskedasticity-robust standard errors clustered at the sector-year level are reported in parentheses. $* *$, **, and * indicate significance at the 1,5 , and 10 percent levels respectively.

working in an industry that experienced the average reduction in tariffs of 14 percentage points are 2 percentage points more likely to hold a formal job than individuals in an industry facing no reduction in tariffs. In column (2), the interaction between sectoral tariffs and the female dummy is insignificant. The impact of trade liberalization on formal employment within four-digit sectors does not vary across gender. In columns (3) and (4), the sectoral tariff measure is interacted with workers' level of education. Column (3) shows that trade liberalization does not affect high-skilled and low-skilled workers differently. Column (4) confirms a similar result for gender. Overall, both men and women, regardless of their level of education, have higher chances of being formal employees if they work in an industry that experiences a decline in tariff.

As discussed in section 4, the increases in the probability of formal employment within tradable industries following trade liberalization may be due to a reallocation of employment towards trade-oriented firms. These firms, which are expanding to exploit larger exporting opportunities, tend also to be more intensive in formal jobs (see Nataraj [2011] and McCaig and Pavcnik [2015] among others). To further investigate the effect of trade liberalization on formal employment within tradable sectors, in the last column of table 3 we consider the role of firm heterogeneity. Although we do not observe the specific firm in 
which workers are employed, we have information about the size of the company, measured by number of employees, where each individual works. Since trade-oriented firms are bigger than firms operating only in the domestic market, firm size captures part of the difference between exporting and domestic firms. Column (5) shows how firm size is related to formality and how the effect of trade policy differs across firms within each sector. We control for four classes of firm size: firms with 10 or fewer employees, firms with between 11 and 50 employees, firms with between 51 and 250 employees, and finally firms with more than 250 employees. ${ }^{20}$ The estimated coefficients of the firm size dummies show that the probability of holding a formal job is higher in larger firms. This finding is in line with the literature on firms and informality, which shows that informal firms tend to be smaller (see La Porta and Shleifer [2014] and McCaig and Pavcnik [2015] among others). Considering the effect of a change in trade policy, workers in smaller firms are less likely to hold a formal job with a drop in tariffs. Trade liberalization increases the probability of holding a formal job only for workers in medium and large firms (more than 50 employees), with the largest effect for firms with more than 250 employees. Finally, we find no gender differences in the effect of tariffs across firms. ${ }^{21}$ Findings in column (5) suggest that trade-oriented firms are more likely to employ formal workers and drive the increase in the probability of being formally employed within sectors following trade liberalization.

\section{Sensitivity Analysis of Industry Results}

To evaluate the effect of trade liberalization on employment composition, we use Mexican tariffs as the main measure of trade policy. However other changes might be both responsible for changes in formality rates and correlated with Mexican trade liberalization. For instance, changes in the composition of the labor force, sectoral gender composition, and other contemporaneous shocks such as inflows of foreign direct investment, exchange rate volatility, and changes in U.S. import tariffs. Therefore, table 4 accounts for these potential omitted variables.

To address the issue of worker selection on unobservable characteristics, we have included in all regressions individual determinants of labor force participation and formal work status that are related to the household characteristics. In particular, we control for marital status (whether she/he lives with a partner), head of the household, migration background, the number of household members, the highest level of education in the household, and the share of household members holding a formal job. All these characteristics are interacted with the gender dummy to allow for different selection processes by gender. ${ }^{22}$ To further control for changes in the composition of the labor force, all columns in table 4 control for birth-year cohorts fixed-effects. This enables us to account for cohort-specific unobservable characteristics related to the labor market entry of new cohorts. To take into consideration the relationship between changes in tariffs and changes in the gender composition of sectors, columns (2) to (4) include the lag of the sector-specific share of female workers. This latter is constructed as the number of female workers in a given sector over the total number of workers in that sector.

To account for other contemporaneous shocks, in columns (3) and (4) we include inflows of foreign direct investment entering Mexico and exchange rate movements, respectively. Data on inflows of foreign direct investment (FDI) come from the OECD International direct investment database (Isic Rev. 3 classification). The quarterly real exchange rate between Mexico and the United States is obtained from

21 Results available upon request.

22 Living with a partner increases the probability of working formally for men but has no effect for women. Similarly, the head of the household is more likely to hold a formal job, especially among male heads of household. Both findings are consistent with a traditional division of roles within the household. Migration reduces the probability of holding a formal job, and even more so for women. The probability of having a formal job increases with the share of household members holding a formal job which corresponds to a social norm and/or network effect. This effect is stronger for men. Similar results are found for Brazil in Ben Yahmed (2018). 
Table 4. Within-Industry Tariff Changes and Additional Controls

\begin{tabular}{|c|c|c|c|c|c|}
\hline \multirow[t]{2}{*}{ Dependent variable } & \multicolumn{5}{|c|}{ Probability of Working Formally among Employees in Manufacturing Sectors } \\
\hline & (1) & $(2)$ & (3) & (4) & (5) \\
\hline$\tau_{s t}$ & $\begin{array}{l}-0.147^{* * *} \\
(0.051)\end{array}$ & $\begin{array}{l}-0.148 * * * \\
(0.051)\end{array}$ & $\begin{array}{l}-0.150 * * * \\
(0.052)\end{array}$ & $\begin{array}{l}-0.150 * * * \\
(0.052)\end{array}$ & $\begin{array}{c}-0.127^{* *} \\
(0.062)\end{array}$ \\
\hline$\tau_{s t} \times$ female & $\begin{array}{c}0.009 \\
(0.036)\end{array}$ & $\begin{array}{c}0.007 \\
(0.036)\end{array}$ & $\begin{array}{c}0.007 \\
(0.036)\end{array}$ & $\begin{array}{c}0.007 \\
(0.036)\end{array}$ & $\begin{array}{c}0.006 \\
(0.053)\end{array}$ \\
\hline Female share $_{s, t-1}$ & & $\begin{array}{c}0.025 \\
(0.027)\end{array}$ & $\begin{array}{c}0.023 \\
(0.028)\end{array}$ & $\begin{array}{c}0.023 \\
(0.028)\end{array}$ & $\begin{array}{c}0.058 \\
(0.036)\end{array}$ \\
\hline $\mathrm{FDI}_{s t}$ & & & $\begin{array}{c}0.000 * \\
(0.000)\end{array}$ & $\begin{array}{c}0.000 \% \\
(0.000)\end{array}$ & $\begin{array}{c}-0.000 * * \\
(0.000)\end{array}$ \\
\hline $\mathrm{RER}_{q, M E X-U S}$ & & & & $\begin{array}{c}-0.000 \\
(0.000)\end{array}$ & $\begin{array}{c}-0.000 \\
(0.000)\end{array}$ \\
\hline$\tau_{U S, s t}$ & & & & & $\begin{array}{c}-0.255^{* *} \\
(0.112)\end{array}$ \\
\hline Observations & 674,206 & 673,105 & 669,967 & 669,967 & 357,253 \\
\hline R-squared & 0.265 & 0.265 & 0.265 & 0.265 & 0.299 \\
\hline Year FE & Yes & Yes & Yes & Yes & Yes \\
\hline Municipality & Yes & Yes & Yes & Yes & Yes \\
\hline 4-digit sector FE & Yes & Yes & Yes & Yes & Yes \\
\hline Cohort FE & Yes & Yes & Yes & Yes & Yes \\
\hline
\end{tabular}

Source: Authors' calculations based on the National Urban Employment Survey from the National Institute of Statistics and Geography, Mexico.

Note: The regressions are LPM estimations of equation (7) for the period 1993-2001. The dependent variable equals 1 if the individual is in formal wage employment and 0 if in informal wage employment. $\tau_{s t}$ is the Mexican import tariff applied to U.S. good $s$ in year $t$. Female share se $_{t-1}$ is the female share among employees working in sector $s$ in year $t-1 . F D I_{s t}$ are foreign direct investments in Mexico in sector $s$ in year $t . R E R_{q, M E X-U S}$ is the quarterly real exchange rate computed as $R E R=e \times$ $C P I(U S) / C P I(M e x)$, where $e$ is the nominal exchange rate in U.S. dollars. $\tau_{U S \text {, st }}$ is the U.S. import tariff applied to Mexican good $s$ in year $t$. Individual controls include age, age ${ }_{2}$, years of education, a female dummy, whether she/he lives with a partner, is the head of the household, has migrated, the number of household members, the highest level of education in the household and the share of household members holding a formal job. RER: real exchange rate. Standard errors are clustered at the sector-year level. $* * * *$, and $*$ indicate significance at the 1,5 , and 10 percent levels respectively.

the Central Bank of Mexico. Finally, since NAFTA is a multilateral agreement by which the United States reciprocally lowered import tariff to products from Mexico, column (5) includes U.S. import tariffs. ${ }^{23}$ A decrease in the U.S. tariff increases the probability of being formally employed. This result can be related to the findings in Paz (2014) and McCaig and Pavcnik (2015), who show that reductions in trading partners' tariffs lead to a decrease in informality in Brazil and Vietnam respectively. Column (5) shows that the formalization effect related to the reduction in Mexican import tariff is unaltered, and its magnitude is slightly reduced by the introduction of U.S. tariffs. Overall, the results in table 4 confirm the benchmark findings in table 3. A decrease in tariffs contributes to the formalization of jobs within four-digit industries for all individuals, irrespective of skill level or gender.

Supplementary online appendix S3 provides additional robustness checks. In table S3.1, we control for sector-specific pre-trends in formality rates. More precisely, we control for sector-specific changes in formal labor share over the two preceding years, that is, $\Delta$ formality $_{s,(t-1)-(t-3)}$. Note that pre-trends over a fixed period of time are controlled by the sector fixed-effects. The magnitude of the estimated coefficient marginally decreased, but the benchmark results are confirmed. The formalization effect seems unrelated to pre-existing trends in formality rates across industries facing different tariff declines.

Finally, we test the sensitivity of the results to alternative measures of formal employment. So far we have focused on wage employment and distinguished formal from informal employees using information on access to mandated benefits. We also use an alternative definition of informality that includes 
self-employed workers who own small firms (see Henley, Arabsheibani, and Carneiro 2009). ${ }^{24}$ Table S3.2 in supplementary online appendix S3 shows that the trade-induced formalization of employment within four-digit industries remains significant when we include self-employment in the informality category. Columns (2) to (4) show that now the formalization effect is stronger for women, especially low-skilled women. This can be explained by the lower propensity of women to enter self-employment compared to men.

Any remaining concerns about endogeneity of tariffs due to, for example, political economy of protection are addressed by using instrumental variables for tariffs. The interested reader will find a description of the IV strategy and the results in supplementary online appendix S3.

\section{Regional-Level Analysis}

We now adopt a local labor market approach and estimate the effect of changes in the gender-specific regional tariff on female and male formal employment using the gender-specific municipality tariff described in equation (6). Since we do not control for disaggregated industry fixed-effects, this section accounts for between-sector labor movements within regions.

The local tariff measure, which varies across gender, municipalities, and years, is used in the following specification:

$$
F_{i r t}=\alpha X_{i r t}+\beta_{1} \tau_{m r t} \times \text { male }_{i}+\beta_{2} \tau_{f r t} \times \text { female }_{i}+u_{r}+v_{t}+\epsilon_{i r t}
$$

where $F_{i r t}$ is an indicator that takes the value 1 if individual $i$ is employed as a formal worker in region $r$ at time $t$, and 0 if the individual works as an informal employee. $X_{i s r t}$ is a vector of specific individual characteristics similar to the one used in the specification at the industry level defined by equation (7). $\tau_{m r t}$ and $\tau_{f r t}$ are male and female exposure to the Mexican import tariff in municipality $r$ at time $t$. We interact the gender-specific municipality tariffs with the corresponding gender dummy. Therefore, $\beta_{1}$ and $\beta_{2}$ capture the effect of regional trade liberalization on men's and women's probability of holding a formal job respectively. We control for municipality fixed-effects $u_{r}$ and year fixed-effects $v_{t} . \epsilon_{i s r t}$ is the error term. Since we want to identify the average trade liberalization effect within a municipality, and not the average effect within an industry and municipality, we do not control for four-digit industry fixed-effects.

We allow for different effects of trade liberalization depending on level of education by interacting the regional tariff variable with an indicator variable that equals 1 if the individual has more than nine years of education. Additionally, to disentangle the effects of local exposure to trade liberalization across tradable and nontradable sectors, we interact the regional tariff variable with a one-digit service sector dummy. Similarly to the industry-level regressions, we later perform a set of robustness checks.

\section{Empirical Results for Local Labor Markets}

The literature on the regional effects of trade liberalization does not account for gender differences, and uses a local tariff measure weighted by overall employment in each industry and region. To compare our results with previous findings, we in column (1) we use a local tariff measure that is not gender-specific and not interacted with a gender dummy. In this case, there is no significant effect of changes in local exposure to tariffs on the average probability of working formally. Columns (2) to (5) use gender-specific local tariffs, as described in section 4, and interact them with gender dummies. Our results show that there is a gender dimension in the regional effects of trade liberalization.

More specifically, in column (2), we allow for heterogeneous effects between men and women, and find that men's probability of working formally is significantly affected by changes in regional exposure to tariff barriers. Men living in a region experiencing a 14-percentage-point reduction in tariffs are almost

24 Notice that self-employed workers in the ENEU survey report very small businesses. In fact more than 80 percent of the self-employed have no employees. 
Table 5. Municipality Exposure to Tariffs

\begin{tabular}{|c|c|c|c|c|c|}
\hline \multirow[t]{2}{*}{ Dependent variable } & \multicolumn{5}{|c|}{ Probability of Working Formally among Employees in Manufacturing and Service sectors } \\
\hline & (1) & (2) & (3) & (4) & (5) \\
\hline$\tau_{r t}$ & $\begin{array}{r}-0.162 \\
(0.214)\end{array}$ & & & & \\
\hline$\tau_{m r t}$ & & $\begin{array}{c}-0.416 * * \\
(0.174)\end{array}$ & $\begin{array}{c}-0.372 * * \\
(0.179)\end{array}$ & $\begin{array}{c}-0.727 * * * \\
(0.168)\end{array}$ & $\begin{array}{c}-0.662 * * * \\
(0.172)\end{array}$ \\
\hline$\tau_{m r t} \times$ he & & & $\begin{array}{c}-0.119 * * \\
(0.057)\end{array}$ & & $\begin{array}{c}-0.229 * * * \\
(0.060)\end{array}$ \\
\hline$\tau_{m r t} \times \operatorname{Serv}$ & & & & $\begin{array}{l}0.439 * * * \\
(0.094)\end{array}$ & $\begin{array}{l}0.403 * * * \\
(0.098)\end{array}$ \\
\hline$\tau_{m r t} \times \operatorname{Serv} \times$ he & & & & & $\begin{array}{c}0.129^{*} \\
(0.072)\end{array}$ \\
\hline$\tau_{f r t}$ & & $\begin{array}{r}-0.026 \\
(0.151)\end{array}$ & $\begin{array}{c}0.037 \\
(0.152)\end{array}$ & $\begin{array}{c}-0.597 * * * \\
(0.157)\end{array}$ & $\begin{array}{c}-0.561 \% * \\
(0.160)\end{array}$ \\
\hline$\tau_{f r t} \times$ he & & & $\begin{array}{c}-0.168 * * * \\
(0.050)\end{array}$ & & $\begin{array}{l}-0.160 * * * \\
(0.054)\end{array}$ \\
\hline$\tau_{f r t} \times \operatorname{Serv}$ & & & & $\begin{array}{l}0.803 * * * \\
(0.091)\end{array}$ & $\begin{array}{l}0.934 * * * \\
(0.095)\end{array}$ \\
\hline$\tau_{f r t} \times \operatorname{Serv} \times$ he & & & & & $\begin{array}{c}-0.236 * * * \\
(0.071)\end{array}$ \\
\hline Observations & $2,648,682$ & $2,648,682$ & $2,648,682$ & $2,648,682$ & $2,648,682$ \\
\hline R-squared & 0.102 & 0.103 & 0.103 & 0.127 & 0.128 \\
\hline Year FE & Yes & Yes & Yes & Yes & Yes \\
\hline Municipality FE & Yes & Yes & Yes & Yes & Yes \\
\hline 4-digit sector FE & No & No & No & No & No \\
\hline
\end{tabular}

Source: Authors' calculations based on the National Urban Employment Survey from the National Institute of Statistics and Geography, Mexico.

Note: The regressions are LPM estimations of equation (8) for the period 1993-2001. The sample is composed of workers in both the tradable and nontradable sectors. The dependent variable equals 1 if the individual is in formal wage employment and 0 if in informal wage employment. The local tariff used in column (1) is not gender-specific and not interacted with a gender dummy. $\tau_{r t}$ is the average exposure to Mexican tariffs in municipality $r$ in year $t$. The local tariffs in columns (2) to (5) are gender-specific and are calculated as in equation (6) using as a weight municipality and sectoral gender-specific formal employment in $1993 . \tau_{m r t}\left(\tau_{f r t}\right)$ is the male (female) exposure to Mexican tariffs in municipality $r$ in year $t$. The variable $\tau_{m r t}$ takes positive values for males, and it is equal to 0 for females. Similarly the variable $\tau_{\text {frt }}$ takes positive values for females, and it is equal to 0 for males. The dummy he is equal to 1 if the individual has more than 9 years of education. The dummy Serv is equal to 1 if the individual works in the services. Individual controls include age and age ${ }_{2}$, years of education, a female dummy, whether she/he lives with a partner, is the head of the household, has migrated, the number of household members, the highest level of education in the household and the share of household members holding a formal job. Columns (3) and (5) also include a high level of education dummy (he) for individuals and its interaction with a female dummy. Columns (4) and (5) include a dummy for the service sectors and all necessary interactions with the female and high education dummies. Heteroskedasticity-robust standard errors clustered by municipality-year pairs are reported in parentheses. $* * * *$, and * indicate significance at the 1,5 , and 10 percent levels respectively.

6 percentage points $(14 \times 0.416)$ more likely to hold a formal job compared to men in an unaffected region. However, women's probability of working formally is not significantly affected. In column (3), we control for the individual level of education and interact it with the gender-specific tariff measures. The increase in male formal employment is stronger for high-skilled men. Similarly, high-skilled women are also more likely to work formally in a municipality exposed to a reduction in tariffs.

Over the 1990s, the formality rate evolved differently in the tradable and nontradable sectors (see fig. 2). Thus, in column (4), we exploit the regional variation in tariffs to establish different effects in the manufacturing and service sectors. In the manufacturing sector, the probability of working formally, both for men and women, increases in regions experiencing a reduction in their average tariff. This formalization of employment is greater for male workers, whose probability increases by 10 percentage points with a decline in local tariffs of 14 percentage points $(14 \times 0.727)$. For women, the probability of holding a formal employment increases by 8 percentage points $(14 \times 0.597)$. The gender difference is statistically different. Comparing tables 5 and 3, we see that the formalization effect of trade across manufactur- 
ing sectors is larger than the formalization effect within four-digit manufacturing sectors. This suggests that regional liberalization generates labor reallocation across four-digit manufacturing industries, which contributes to a formalization of employment in these industries, especially for men.

We now examine the effect of regional liberalization on formal employment in the service sectors. In column (4), for both men and women, the tariff coefficient is positive and significant. Nevertheless, for men, it is more than compensated by the negative coefficient associated with $\tau_{m r t}$. Therefore, men's probability of holding a formal job increases with regional trade liberalization in the service sector as well, though less than in the manufacturing sector. In contrast, women employed in the service sectors experience a 3-percentage-point reduction in their probability of working formally following a 14-percentage-point decrease in local tariffs.

In column (5), we add the level of education, and find that the effect of regional tariffs differs across gender, sectors, and levels of education. In the manufacturing sector, a 14-percentage-point decline in the municipality tariff leads to a 12-percentage-point increase in high-skilled men's probability of finding a formal job. The effect is smaller but still positive for high-skilled women, whose probability of holding a formal job increases by 10 percentage points. ${ }^{25}$ In the service sector, the probability of holding a formal job decreases with trade liberalization for low-skilled women only. More specifically, the probability of working formally in the service sector falls by 5 percentage points for women with a low level of education, while highly educated women are not significantly affected. Highly educated men working in the service sector experience a formalization of jobs, whereas low-skilled men do not. To summarize, in the tradable sectors all workers are more likely to work formally when exposed to tariff reductions, and this formalization effect increases with workers' level of education. Similarly in the nontradable sector, higher education reduces the odds of working informally following a decline in regional tariffs. This happens despite the exposure to regional trade liberalization increasing the probability of working informally for low-skilled women.

The results suggest that women and men have been affected differently by trade liberalization. In the manufacturing sector, the formalization of jobs occurred for both men and women, but with different magnitudes. Following the theoretical framework, we interpret the changes in formal employment as driven by reallocation of employment across sectors. The formalization of employment in the tradable sector corresponds to a situation in which comparative advantage sectors, which expand through trade, are intensive in formal labor compared to other tradable and nontradable sectors. Figure S2.1 in supplementary online appendix S2 confirms this for Mexico. During the 1990s Mexican manufacturing sectors with large net export shares are on average more intensive in formal labor than manufacturing sectors with low net export shares. We can also use the model to interpret the finding that the likelihood of holding a formal job has experienced a greater increase for men than for women. In fact, Prediction 2 states that trade liberalization leads to a greater increase in the male formal employment share relative to female formal employment share in cases where male labor is relatively more substitutable for capital than female labor in the CA sectors.

\section{Discussion of Results}

The results on the effect of regional import liberalization contrast with those of other studies on the effect of trade on informality. More specifically, Dix-Carneiro and Kovak (2018) find that Brazilian microregions that are more exposed to import tariff reductions experienced an increase in informality even 20 years after the trade reform. The different results may be driven by the specific sample used, country setting, and methodology. More precisely, the focus on gender differences is relevant because men and women are affected differently by trade policy. In fact, in those municipalities exposed to large import

25 The linear combination $\tau_{f r t}+\tau_{f r t} \times$ he is significant at the 5 percent level. The effect on high-skilled women is statistically different from the effect on high-skilled men at the 1 percent level. 
tariff reductions we find an increase in formality only for men. This result is different from what we find when pooling men and women together, in column (1) of table 5, where the effect of the trade policy reform on informality is insignificant.

Additionally, the data used in this paper only cover urban areas. Because of occupation and industry composition, these areas might be affected differently from rural areas. It is important to notice that, over the 1990s, Mexican urban areas are characterized by a large and increasing share of employment in manufacturing sectors. These sectors have been directly and positively affected by the NAFTA multilateral agreement. In this respect, the results are consistent with the findings in Atkin (2016), who documents a formal employment boom in Mexican export-oriented manufacturing industries: between 1989 and 1999, 65 percent of the growth in formal employment in manufacturing industries stems from export-oriented industries. Moreover, he shows that many of those new jobs were low-skilled jobs, which may have facilitated the move from informal to formal jobs for informal workers with low skills. It is also worth noting that the findings of this study are in line with some of the findings in Menezes-Filho and Muendler (2011). In table 9, they show that lower intermediate-input tariffs are associated with significantly lower odds of transitioning into unemployment and out of the labor force, resulting in a significantly higher number of transitions into formality. However, reductions in product-market tariffs have the opposite effect. In the case of Mexico, export-oriented sectors benefited from the drop in Mexican tariffs as intermediate inputs became cheaper. Indeed, Mexican exports to the United States use a very high share of U.S. inputs (de Gortari 2017). Differences in global supply-chains may be partially responsible for differing effects of import tariff reductions on formal employment across countries.

Finally, unlike Dix-Carneiro and Kovak (2018) who exploit decennial changes, we use annual time series variation in tariffs. Therefore the estimates of this paper capture the short-run effects of trade policy. To compare our findings to longer-term studies such as Dix-Carneiro and Kovak (2018), we also adopt a long difference identification strategy. We use data for 1993 and 2000 to evaluate the effect of local exposure to tariff reduction on formal employment probability. The strategy is described in supplementary online appendix S4, and results are presented in table S4.1. Although the signs of the coefficients are similar to the benchmark results in table 5, the long difference strategy shows no significant effect of trade liberalization on formal employment probability. The need to control for past trends, which are created using municipality information during the 1980s, introduces a limitation. In fact, this information is available only for a small subset of municipalities. This might explain the lack of precision in the estimates.

\section{Robustness Checks for Local Labor Markets}

We now replicate the benchmark estimation for the local labor market approach controlling for potential confounding factors. Table 6 shows the results. To address the issue of worker selection on unobservable characteristics, we have included in all regressions individual determinants of labor force participation and formal work status that are related to household characteristics. To eliminate any bias due to labor market entry of new cohorts during the 1990s, and changing characteristics of the labor force, we include fiveyear birth-cohort dummies in all columns. We also control for lagged municipality characteristics, such as the female share and average level of education in the working population. ${ }^{26}$ Therefore, the results should not reflect changes in the composition of the labor force in municipalities facing different tariff exposure.

Columns (3) to (5) in table 6 control for other macroeconomic contemporary shocks. The inflow of FDI at the municipality level is computed as the employment weighted average of FDI inflows across industries in each municipality and controls for another dimension of globalization that may be correlated with trade in goods. Additionally, the quarterly real exchange rate controls for any macroeconomic impact of peso fluctuations.

26 The female share in a municipality's working population is computed as the number of female workers divided by the total number of workers in that municipality. 
Table 6. Municipality Exposure to Tariffs and Additional Controls

\begin{tabular}{|c|c|c|c|c|c|}
\hline \multirow[t]{2}{*}{ Dependent variable } & \multicolumn{5}{|c|}{ Probability of Working Formally among Employees in Manufacturing and Service sectors } \\
\hline & $(1)$ & $(2)$ & (3) & (4) & $(5)$ \\
\hline$\tau_{m r t}$ & $\begin{array}{l}-0.439 * * * \\
(0.169)\end{array}$ & $\begin{array}{l}-0.434 * * \\
(0.168)\end{array}$ & $\begin{array}{l}-0.425 * * \\
(0.169)\end{array}$ & $\begin{array}{l}-0.783 * * * \\
(0.173)\end{array}$ & $\begin{array}{l}-0.745 * * * \\
(0.176)\end{array}$ \\
\hline$\tau_{m r t} \times$ he & & & & & $\begin{array}{l}-0.149 * * \\
(0.060)\end{array}$ \\
\hline$\tau_{m r t} \times \operatorname{Serv}$ & & & & $\begin{array}{l}0.471 * * * \\
(0.102)\end{array}$ & $\begin{array}{l}0.431 * * * \\
(0.105)\end{array}$ \\
\hline$\tau_{m r t} \times \operatorname{Serv} \times$ he & & & & & $\begin{array}{c}0.130 * \\
(0.076)\end{array}$ \\
\hline$\tau_{f r t}$ & $\begin{array}{r}-0.078 \\
(0.146)\end{array}$ & $\begin{array}{r}-0.033 \\
(0.147)\end{array}$ & $\begin{array}{r}-0.035 \\
(0.147)\end{array}$ & $\begin{array}{l}-0.768 * * * \\
(0.162)\end{array}$ & $\begin{array}{l}-0.726^{* * *} \\
(0.164)\end{array}$ \\
\hline$\tau_{f r t} \times$ he & & & & & $\begin{array}{l}-0.169^{* * *} \\
(0.054)\end{array}$ \\
\hline$\tau_{f r t} \times \operatorname{Serv}$ & & & & $\begin{array}{l}0.939 * * * \\
(0.098)\end{array}$ & $\begin{array}{l}1.057^{* * *} \\
(0.101)\end{array}$ \\
\hline$\tau_{f r t} \times \operatorname{Serv} \times$ he & & & & & $\begin{array}{l}-0.211^{* * *} \\
(0.075)\end{array}$ \\
\hline$\tau_{U S, m r t}$ & & $\begin{array}{r}-0.123 \\
(0.203)\end{array}$ & $\begin{array}{r}-0.044 \\
(0.235)\end{array}$ & $\begin{array}{r}-0.075 \\
(0.231)\end{array}$ & $\begin{array}{r}-0.083 \\
(0.229)\end{array}$ \\
\hline$\tau_{U S, f r t}$ & & $\begin{array}{c}-0.427^{*} \\
(0.248)\end{array}$ & $\begin{array}{c}-0.303 \\
(0.268)\end{array}$ & $\begin{array}{r}-0.051 \\
(0.258)\end{array}$ & $\begin{array}{r}-0.060 \\
(0.256)\end{array}$ \\
\hline $\mathrm{FDI}_{r, t}$ & & & $\begin{array}{l}0.000 * * * \\
(0.000)\end{array}$ & $\begin{array}{l}0.000 * \\
(0.000)\end{array}$ & $\begin{array}{c}0.000 * \\
(0.000)\end{array}$ \\
\hline $\mathrm{RER}_{q, M E X-U S}$ & & & $\begin{array}{l}0.001 * * * \\
(0.000)\end{array}$ & $\begin{array}{l}0.001 * * * \\
(0.000)\end{array}$ & $\begin{array}{l}0.000 * * * \\
(0.000)\end{array}$ \\
\hline Educ working pop $r, t-1$ & $\begin{array}{c}0.003 \\
(0.003)\end{array}$ & $\begin{array}{c}0.003 \\
(0.003)\end{array}$ & $\begin{array}{l}0.005 \\
(0.003)\end{array}$ & $\begin{array}{l}0.005 \\
(0.003)\end{array}$ & $\begin{array}{c}0.005 \\
(0.003)\end{array}$ \\
\hline Female share $_{r, t-1}$ & $\begin{array}{c}-0.509 * * \\
(0.082)\end{array}$ & $\begin{array}{l}-0.539 * * * \\
(0.088)\end{array}$ & $\begin{array}{l}-0.476^{* * *} \\
(0.091)\end{array}$ & $\begin{array}{l}-0.344 * * * \\
(0.090)\end{array}$ & $\begin{array}{l}-0.357^{* * *} \\
(0.090)\end{array}$ \\
\hline Female share $_{r, t-1} \times \mathrm{fe}$ & $\begin{array}{l}0.250 * * \\
(0.064)\end{array}$ & $\begin{array}{l}0.261 * * \\
(0.067)\end{array}$ & $\begin{array}{l}0.203 * * \\
(0.075)\end{array}$ & $\begin{array}{l}0.143 * * \\
(0.064)\end{array}$ & $\begin{array}{l}0.156^{* *} \\
(0.064)\end{array}$ \\
\hline Observations & $2,647,786$ & $2,615,443$ & $2,313,412$ & $2,313,412$ & $2,313,412$ \\
\hline R-squared & 0.114 & 0.112 & 0.113 & 0.139 & 0.140 \\
\hline Year FE & Yes & Yes & Yes & Yes & Yes \\
\hline Municipality & Yes & Yes & Yes & Yes & Yes \\
\hline 4-digit sector FE & No & No & No & No & No \\
\hline Birth-cohort FE & Yes & Yes & Yes & Yes & Yes \\
\hline
\end{tabular}

Source: Authors' calculations based on the National Urban Employment Survey from the National Institute of Statistics and Geography, Mexico.

Note: The regressions are LPM estimations of equation (8) for the period 1993-2001. $\tau_{m r t}\left(\tau_{f r t}\right)$ is the male (female) exposure to Mexican tariffs in municipality $r$ in year $t . \tau_{U S, m r t}\left(\tau_{U S, f r t}\right)$ is the male (female) exposure to U.S. tariffs in municipality $r$ in year $t$. The variable $\tau_{m r t}$ takes positive values for males, and it is equal to 0 for females. Similarly the variable $\tau_{f r t}$ takes positive values for females, and it is equal to 0 for males. The dummy he is equal to 1 if the individual has more than 9 years of education. The dummy Serv is equal to 1 if the individual works in the services. FDI $I_{r t}$ is the local exposure to foreign direct investments in municipality $r$ in year $t$. RER $R_{q, M E X-U S}$ is the quarterly real exchange rate computed as RER $=e \times C P I(U S) / C P I(M e x)$, where $e$ is the nominal exchange rate in U.S. dollars. Educ working pop $p_{r, t-1}$ is the average level of education among employees working in municipality $r$ in year $t-1$. Female share $r, t-1$ is the female share among employees working in municipality $r$ in year $t-1$. Individual controls include age, age 2 , years of education, a female dummy, whether she/he lives with a partner, is the head of the household, has migrated, the number of household members, the highest level of education in the household and the share of household members holding a formal job. Standard errors are clustered at the municipality-year level. $* * * *$, and * indicate significance at the 1,5 , and 10 percent levels respectively. 
To account for the nature of the trade reform, that is, import liberalization versus export market liberalization, we control for gender-specific local exposure to U.S. import tariffs in columns (2) to (5). Exposure to reductions in U.S. tariffs increases the probability of holding a formal job for women and only in column (2). The inclusion of this variable does not alter the magnitude or significance of the Mexican tariff. The exposure to Mexican tariff reductions does not capture the effect of exposure to concomitant reductions in U.S. tariffs.

To better explore the role of a trade partner's tariffs reduction on formal employment, we replicate the analysis focusing exclusively on U.S. local exposure. The results are in table S5.1 in supplementary online appendix S5. Reductions in U.S. tariffs have similar effects to reductions in Mexican import tariff, increasing formal employment probability for men overall. High-skilled women are more likely to work formally if they live in a region exposed to a significant reduction in U.S. tariffs. However, low-skilled women are less likely to work formally. Reductions in U.S. tariffs increase the probability of working formally in the manufacturing sectors for both men and women, but reduce the probability of working formally for women in the service sectors.

To address the issue of pre-existing trends we control for municipalies' trends in formality rates in the previous two years using a time-rolling window. Results are shown in table S5.2 in supplementary online appendix S5 and confirm that the results are not merely driven by differences in pre-existing trends across regions facing different tariff declines.

In another sensitivity check, we account for a broader definition of employment, and include selfemployed individuals in the informal employment category. Table S5.3 reports the results and confirms the benchmark findings for the effect of trade liberalization on regional labor markets. Similarly to the benchmark results in table 5, we find that, in the manufacturing sector, the probability of being in formal employment increases, while in the service sectors informal employment increases for low-skilled women.

\section{Employment Margins}

The theoretical framework stresses labor reallocation across sectors as a mechanism through which trade affects formal relative to informal employment. An alternative mechanism is related to shifts between employment and non-employment (Menezes-Filho and Muendler 2011; Gaddis and Pieters 2017). We then explore additional employment margins to evaluate the impact of trade liberalization on formality across gender, and use an alternative sample composed of the whole working-age population. In addition to individuals in formal and informal paid employment, our new sample also includes individuals who are not in paid employment, either because they are unemployed or out of the labor force. Table S6.1 in supplementary online appendix S6 presents the results. In column (1), the dependent variable takes the value 1 if the individual is in paid employment (either in formal or informal employment), and the value 0 if the individual is not in paid employment (either unemployed or out of the labor force). Column (1) shows that trade liberalization contributes to a small increase in female paid employment probability, but did not lead to a significant change in male paid employment probability. These findings differ from those in Gaddis and Pieters (2017) for Brazil, where the exposure to trade liberalization has instead reduced labor force participation for both men and women.

We then consider shifts from formal employment into informal employment and non-employment. Specifically, columns (2) to (5) use as a dependent variable a categorical variable equal to 1 if the individual holds a formal job, and to 0 if she/he is either an informal worker, unemployed, or out of the labor force. Column (2) shows that both women and men are more likely to be formally employed with stronger exposure to trade liberalization. This differs from our benchmark results, in column (2) of table 5, where the effect of local tariffs is insignificant for women. Therefore, we conclude that exposure to tariff reduction has contributed to the movement of women from non-employment into formal employment. Using Brazilian household panel data, Menezes-Filho and Muendler (2011) find that a reduction in intermediate inputs tariffs decreases the probability of transitions from formal employment into unemployment 
and nonparticipation. In other words, it increases the probability of remaining in or moving to formal employment. Meanwhile, they find the opposite effect for reductions in product market tariffs. Similarly to their findings for intermediate input tariffs, we find that the likelihood of formal employment relative to other employment statuses has increased with Mexican tariff reductions.

Comparing tradable and nontradable sectors, column (4) in table S6.1 shows that accounting for the employment margin confirms the formalization effect of trade liberalization in the manufacturing sector, and the informalization of female jobs in the service sector. Similarly to the benchmark results, column (5) shows that the decrease in women's formal employment probability in the service sectors is driven by low-skilled women.

\section{Conclusions}

In this paper we theoretically and empirically analyze the link between trade liberalization and formal employment, allowing for gender differences. We estimate how changes in import tariffs affect men's and women's probability of holding a formal job both at the industry and municipality level using Mexican individual data and tariff information at the four-digit industry category. We find that a fall in the Mexican import tariff generates a formalization of employment within four-digit manufacturing sectors for both men and women, especially for those employed in large firms. We interpret the withinindustry findings as evidence of labor reallocation towards trade-oriented firms with higher formal job shares.

Constructing a weighted average of tariffs at the municipality level, we show that the local effects of changes in trade policy vary across gender and sectors. We find that, in the manufacturing sector, trade liberalization increased the probability of working formally for both women and men, and especially for men. Consistent with our theoretical predictions, the results at the local level can be explained by the reallocation of employment into comparative advantage sectors, which are relatively more intensive in formal jobs, and where male labor is relatively more substitutable for capital than female labor. Regional trade liberalization contributes to the formalization of jobs in tradable sectors, but not necessarily in the nontradable sectors. We find that, in the service sectors, women, especially those with a low educational level, experience an increase in informality. The increase in informality among female employees in the service sector may raise challenges for gender equality.

Our main contribution is to extend previous studies on globalisation and gender by analyzing the effect of trade liberalization on gender differences in access to formal jobs. The paper remains silent about the potential impact of trade liberalization on male and female wages in formal and informal jobs. Exploring this channel may further improve our understanding of gender inequality in the labor market, and additional research is needed in this direction.

\section{References}

Aguayo-Tellez, E., J. Airola, and C. Juhn. 2010. "Did Trade Liberalization Help Women? The Case of Mexico in the 1990s." Research in Labor Economics 38: 1-35.

Aleman-Castilla, B., 2006. "The Effect of Trade Liberalization on Informality and Wages: Evidence from Mexico.” Discussion Paper No. 763, Centre for Economic Performance (CEP), London School of Economics, London.

Atkin, D. 2016. “Endogenous Skill Acquisition and Export Manufacturing in Mexico.” American Economic Review 106 (8): 2046-85.

Autor, D., D. Dorn, and G. Hanson. 2013. "The China Syndrome: Local Labor Market Effects of Import Competition in the United States." American Economic Review 103 (6): 2121-68.

- 2018. "When Work Disappears: Manufacturing Decline and the Falling Marriage-Market Value of Young Men." American Economic Review: Insights, forthcoming. 
Becker, D., 2017. "Heterogeneous Firms and Informality: the Effects of Trade Liberalization on Labor Markets." Oxford Economic Papers 70 (1): 47-72.

Ben Yahmed, S., 2012. "Gender Wage Discrimination and Trade Openness: Prejudiced Employers in an Open Industry.” Working Paper Series No. 2012-33, Aix-Marseille School of Economics, Marseille, France.

- 2018. "Formal but Less Equal: Gender Wage Gaps in Formal and Informal Jobs in Urban Brazil." World Development 101: 73-87.

Black, S. E., and E. Brainerd. 2004. "Importing Equality? The Impact of Globalization on Gender Discrimination." Industrial and Labor Relations Review 57 (4): 540-59.

Black, S. E., and A. Spitz-Oener. 2010. "Explaining Women's Success: Technological Change and the Skill Content of Women's Work." Review of Economics and Statistics 92 (1): 187-94.

Blum, B. S. 2008. "Trade, Technology, and the Rise of the Service Sector: The Effects on US Wage Inequality.” Journal of International Economics 74 (1): 441-58.

Bosch, M., and M. Manacorda. 2010. “Minimum Wages and Earnings Inequality in Urban Mexico.” American Economic Journal: Applied Economics 2 (4): 128-49.

Bosch, M., E. Goñi-Pacchioni, and W. Maloney. 2012. "Trade Liberalization, Labor Reforms and Formal-Informal Employment Dynamics.” Labor Economics 19 (5): 653-67.

Chiquiar, D. 2008. "Globalization, Regional Wage Differentials and the Stolper-Samuelson Theorem: Evidence from Mexico." Journal of International Economics 74 (1): 70-93.

Cruces, G., G. Porto, and M. Viollaz. 2018. "Trade Liberalization and Informality in Argentina: Exploring the Adjustment Mechanisms.” Documento de Trabajo Nro. 229, CEDLAS, June 2018.

de Gortari, A. 2017. "Disentangling Global Value Chains.” Mimeo. Available at: https:/static1.squarespace.com/ static/5abbce40710699dd7ac501dd/t/5abbecbc575d1fb78ee87d0f/1522265334574/deGortari_2017.pdf.

De Sousa, J., T. Mayer, and S. Zignago. 2012. "Market Access in Global and Regional Trade.” Regional Science and Urban Economics 42 (6): 1037-52

Dix-Carneiro, R., and B. K. Kovak. 2015. "Trade Liberalization and the Skill Premium: A Local Labor Markets Approach." American Economic Review: Papers and Proceedings 105 (5): 551-57.

—. 2017. "Trade Liberalization and Regional Dynamics." American Economic Review 107 (10): 2908-46.

- 2018. "Margins of Labor Market Adjustment to Trade." Journal of International Economics, forthcoming.

Do, Q., A. Levchenko, and C. Raddatz. 2016. “Comparative Advantage, International Trade, and Fertility.” Journal of Development Economics 119 (1): 48-66.

Edmonds, E., P. Topalova, and N. Pavcnik. 2009. "Child Labor and Schooling in a Globalizing World: Some Evidence from Urban India." Journal of the European Economic Association 7 (2-3): 498-507.

- 2010. "Trade Adjustment and Human Capital Investments: Evidence from Indian Tariff Reform." American Economic Journal: Applied Economics 2 (4): 42-75.

Feenstra, R. C., J. Romalis, and P. K. Schott. 2002. “U.S. Imports, Exports, and Tariff Data, 1989-2001,” NBER Working Paper No. 9387, National Bureau of Economic Research, Cambridge, MA.

Gaddis, I., and J. Pieters. 2017. "The Gendered Labor Market Impacts of Trade Liberalization: Evidence from Brazil.” Journal of Human Ressources 52 (2): 457-90.

Galor, O., and D. N. Weil. 1996. "The Gender Gap, Fertility, and Growth.” American Economic Review 86 (3): 374-87.

Goldberg, P. K., and N. Pavcnik. 2003. "The Response of the Informal Sector to trade Liberalization." Journal of Development Economics 72 (2): 463-96.

- 2005. "Trade, Wages, and the Political Economy of Trade Protection: Evidence from the Colombian Trade Reforms." Journal of International Economics 66 (1): 75-105.

- 2007. "Distributional Effects of Globalization in Developing Countries." Journal of Economic Literature 45 (1): 39-82.

Hanson, G. H. 2007. "Globalization, Labor Income, and Poverty in Mexico.” In Globalization and Poverty, edited by A. Hanson, 417-56. Chicago: University of Chicago Press and the National Bureau of Economic Research.

Henley, A., G. R. Arabsheibani, and F. G. Carneiro. 2009. "On Defining and Measuring the Informal Sector: Evidence from Brazil.” World Development 3 (7): 992-1003. 
Iacovone, L., and B. Javorcik. 2010. "Multi-Product Exporters: Product Churning, Uncertainty and Export Discoveries." Economic Journal 120 (544): 481-99.

Iacovone, L., B. Javorcik, W. Keller, and J. Tybout. 2015. “Supplier Responses to Walmart's Invasion in Mexico.” Journal of International Economics 95 (1): 1-15.

Jones, R. W. 1975. "Income Distribution and Effective Protection in a Multicommodity Trade Model.” Journal of Economic Theory 11 (1): 1-15.

Juhn, C., G. Ujhelyi, and C. Villegas-Sanchez. 2013. “Trade Liberalization and Gender Inequality.” American Economic Review 103 (3): 269-73.

- 2014. "Men, Women, and Machines: The Impact of Trade on Gender Inequality." Journal of Development Economics 106, 179-93.

Jütting, J., and J. R. De Laiglesia. 2009. Is Informal Normal? Towards More and Better Jobs in Developing Countries. Washington, DC: OECD Publishing.

Kis-Katos, K., and R. Sparrow. 2015. "Poverty, Labor Markets and Trade Liberalization in Indonesia." Journal of Development Economics 117: 94-106.

Kovak, B. 2013. "Regional Effects of Trade Reform: What Is the Correct Measure of Liberalization?" American Economic Review 103 (5): 1960-76.

La Porta, R., and A. Shleifer. 2014. "Informality and Development." Journal of Economic Perspectives 28 (3): 109-26.

McCaig, B., and N. Pavcnik. 2015. "Informal Employment in a Growing and Globalizing Low-Income Country." American Economic Review 105 (5): 545-50.

- 2018. "Export Markets and Labor Allocation in a Poor Country." American Economic Review 108 (7): 1899-1941.

Menezes-Filho, N. A., and M. Muendler. 2011. “Labor Reallocation in Response to Trade Reform.” NBER Working Paper No. 17372, National Bureau of Economic Research, Cambridge, MA.

Nataraj, S. 2011. "The Impact of Trade Liberalization on Productivity: Evidence from India's Formal and Informal Manufacturing Sectors." Journal of International Economics 85 (2): 292-301.

Paz, Lourenco S. 2014. "The Impacts of Trade Liberalization on Informal Labor Markets: A Theoretical and Empirical Evaluation of the Brazilian Case.” Journal of International Economics 92 (2): 330-48.

Robertson, R. 2004. "Relative Prices and Wage Inequality: Evidence from Mexico." Journal of International Economics 64 (2): 387-409.

Sauré, P., and Zoabi H. 2014. "International Trade, the Gender Wage Gap and Female Labor Force Participation." Journal of Development Economics 111: 17-33.

Topalova, P. 2010. "Factor Immobility and Regional Impacts of Trade Liberalization: Evidence on Poverty from India." American Economic Journal: Applied Economics 2 (4): 1-41.

Ulyssea, G. 2017. "Firms, Informality and Development: Theory and Evidence from Brazil." American Economic Review 108 (8): 2015-47.

Verhoogen, E., 2008. “Trade, Quality Upgrading and Wage Inequality in the Mexican Manufacturing Sector.” Quarterly Journal of Economics 123 (2): 489-530. 